Prethodno priopćenje

UDK: 65.014:664>(497.5-35Splitsko-dalmatinska)

Datum primitka članka u uredništvo: 13. 4. 2018.

Datum slanja članka na recenziju: 17. 4.2018.

Datum prihvaćanja članka za objavu: 5. 6. 2018.

Doc. dr. sc. Željko Mateljak *

Prof. dr. sc. Želimir Dulčić ${ }^{* *}$

Zoran Ljoljicic ${ }^{* * *}$

\title{
UTJECAJ PRIMIJENJENIH TIPOVA ORGANIZACIJSKIH STRUKTURA NA EFIKASNOST PODUZEĆA U PREHRAMBENOJ INDUSTRIJI SPLITSKO-DALMATINSKE ŽUPANIJE
}

\author{
THE IMPACT OF DIFFERENT ORGANIZATIONAL \\ STRUCTURES ON THE FIRMS EFFICIENCY IN THE FOOD \\ INDUSTRY: A CASE OF SPLIT-DALMATIA COUNTY
}

\begin{abstract}
SAŽETAK: Organizacijska struktura podrazumijeva ukupnost odnosa i veza između čimbenika u poslovnoj organizaciji. Predmet istraživanja u ovome radu je vezan uz ispitivanje utjecaja tipova organizacijske strukture na efikasnost poduzeća u prehrambenoj industriji Splitsko-dalmatinske županije. Cilj istraživanja je utvrditi koji je tip organizacijske strukture primjeren poduzećima u prehrambenoj industriji Splitsko-dalmatinske županije kako bi se primjenom optimalnog tipa organizacijske strukture povećala njihova efikasnost. Rezultati istraživanja pokazuju da ne postoji statistički značajna razlika između funkcijske i divizijske organizacijske strukture s obzirom na efikasnost poslovanja poduzeća u prehrambenoj industriji Splitsko-dalmatinske županije te da postoji statistički značajna razlika između poduzeća koja koriste strategiju, kao jedan od faktora utjecaja na izbor organizacijske strukture i poduzeća koja koriste okolinu prilikom izbora organizacijske strukture.
\end{abstract}

KLJUČNE RIJEČI: organiziranje, organizacijska struktura, efikasnost, prehrambena industrija, Splitsko-dalmatinska županija.

ABSTRACT: Organizational structure implies the totality of relationships and relationships between the factors in the business organization. The subject of the research

Doc. dr. sc. Željko Mateljak, Ekonomski fakultet, Sveučilište u Splitu, Cvite Fiskovića 5, 21000 Split, e-mail: zeljko.mateljak@efst.hr.

** Prof. dr. sc. Želimir Dulčić, redoviti profesor u trajnom zvanju, Ekonomski fakultet, Sveučilište u Splitu, Cvite Fiskovića 5, 21000 Split, e-mail: zdulcic@efst.hr.

*** Zoran Ljoljić, student, Ekonomski fakultet, Sveučilište u Splitu, Cvite Fiskovića 5, 21000 Split, e-mail: zoran-ljoljic@hotmail.com. 
in this paper is related to the examination of the influence of the types of organizational structure on the efficiency of the companies in the food industry of the Split-Dalmatia County. The aim of the research is to determine which type of organizational structure is appropriate for the companies in the food industry of the Split-Dalmatia County in order to maximize their efficiency using the optimal type of organizational structure. The research results show that there is no statistically significant difference between the functional and divisional organizational structure with regard to the efficiency of the business of the food industry of the Split-Dalmatia County and that there is a statistically significant difference between the companies using the strategy as one of the factors influencing the choice of organizational structure, and companies that use the environment when choosing an organizational structure.

KEY WORDS: organization, organization structure, efficiency, food industry, Split - Dalmatia County.

\section{UVOD}

Riječ struktura (lat. structura, od struere - slagati, sklapati, zidati) ima više različitih značenja. Pod riječju struktura podrazumijeva se primjerice građa, sastav, sklop, raspored, način gradnje, tvorevine, organizam. Iz tih značenja riječi struktura može se zaključiti i važnost strukture uopće, a posebno za poduzeće (Sikavica, Bahtijarević-Šiber i Pološki-Vokić, 2008., str. 294.).

Organizacijska struktura je temelj povezanosti između poslova, sustava, operativnih procesa, ljudi i grupa koji ulažu napore ka postizanju ciljeva (Ahmady, Mehrpour i Nikooravesh, 2016., str. 455.). Svaka organizacija, pa tako i poduzeće, ima određenu strukturu odnosno sastav, tj. neki svoj sastav unutarnjih veza i odnosa. Važnost strukture za poduzeće jednaka je važnosti anatomije za ljudski ili neki drugi živi organizam, pa se ona često naziva i anatomijom organizacije odnosno anatomijom poduzeća (Medić, 2015.).

Organizacijska struktura predstavlja dinamičan element organizacije - mijenja se ovisno o utjecajnim čimbenicima organizacije, koji izazivaju potrebu za promjenama u organizacijskoj strukturi poduzeća (Medić. 2015.) ili podrazumijeva sveukupnost veza i odnosa između činitelja proizvodnje, kao i sveukupnost veza i odnosa unutar svakog pojedinog činitelja proizvodnje odnosno poslovanja (Žugaj i Brčić, 2003., str. 146.).

Osnovna podjela organizacijske strukture, iz koje proistječe njena uloga i značaj, je na mehanicističke i organske organizacijske strukture. Mehanicističke organizacijske strukture su one organizacijske strukture koje karakterizira rigidnost (krutost), složenost i formaliziranost, primjena strogih pravila i usko definiranih zadataka, visoki stupanj centralizacije, podjela rada i specijalizacija te uži raspon kontrole i vertikalni sustav komuniciranja. U mehanicističke organizacijske strukture spadaju (Buble, 2006., str. 208.):

- Funkcijska organizacijska struktura - podrazumijeva grupiranje svih istovrsnih ili sličnih poslova u jednu organizacijsku jedinicu.

- Divizijska organizacijska struktura - podrazumijeva da se svi poslovi koji su zajednički za jedan proizvod, grupu proizvoda, proizvodnu liniju ili zemljopisno područje grupiraju u jednu organizacijsku jedinicu koja postaje neovisna. 
- Matrična organizacijska struktura - podrazumijeva grupiranje poslova prema principima funkcijske i divizijske organizacijske strukture.

S druge strane, u organske organizacijske strukture spadaju (Buble, 2006., str. 208209.):

- Procesna organizacijska struktura - podrazumijeva grupiranje poslova oko središnjih (core) procesa formiranjem multidiscipliniranih timova.

- Mrežna organizacijska struktura - podrazumijeva međusobno elektronički povezane autonomne grupe pomoću središnjeg brokera s kojima ugovaraju usluge radi ostvarivanja profita.

Organizacijske strukture se također mogu podijeliti na tradicionalne/klasične strukture, organske/adaptivne strukture i mrežne strukture (Sikavica i Novak, 1999., str. 165-170.).

Organizacijska struktura koja je jednom postavljena nije statična nego dinamična varijabla poslovanja poduzeća koja je podložna promjenama bez prekida kontinuiteta poslovanja u poduzeću. Za to je potreban iskusan menadžment koji je upoznat sa sadašnjim procesima u poduzeću te koji stalno analizira postojeći organizacijski koncept poslovanja kako bi se pravovremeno mogla napraviti promjena strukture. Stoga, zastarjela organizacijska struktura, koja više ne odgovara potrebama poduzeća, znači da poduzeće služi strukturi, a ne struktura poduzeću te može imati negativne posljedice na poslovni rezultat poduzeća.

Upravljanje promjenama i razvojem organizacije ne bi bili važni da su proizvodi i tržišta stabilni i da su organizacijske promjene rijetke. Promjena je sveprisutni popratni element organizacijskog života, iako mnogi ističu kako se opseg i stupanj promjena znatno povećao proteklih desetljeća (Burnes, 2000., str. 251.). Promjena je prisutna u poslovnom svijetu stoljećima i zasigurno će tako biti i dalje, ali sama ideja o promjeni se mijenja (Abrahamson, 2000., str. 79.).

Stoga, na primjenu tipa organizacijske strukture utječu brojni unutarnji i vanjski čimbenici koji određuju tip okoline u kojoj poduzeće posluje. Kako bi poduzeće moglo opstati na tržištu pod tim danim uvjetima (čimbenicima), potrebno je dizajnirati takav tip organizacijske strukture koji će efikasno odgovarati na zahtjeve okoline. Riječ je o čimbenicima organizacijske strukture poduzeća koji mogu biti vanjski i unutarnji (Hernaus, 2009., str. 16.):

- Unutarnji (endogeni) čimbenici koji određuju poduzeće, a samim time i oblikovanje organizacijske strukture su oni koji ,izviru“ iz samog organizacijskog rješenja ili oni koji su pod izravnim utjecajem menadžmenta. To su, prije svega, koncepcija same organizacije, zatim homogenost organizacijskog rješenja u cjelini i homogenost svakoga pojedinog rješenja, metode i postupci oblikovanja organizacijskog rješenja, baš kao i ciljevi, strategija, primijenjena tehnologija, lokacija, veličina, zaposlenici, proizvodi i životni ciklus organizacije. Među najznačajnije spadaju: ciljevi, strategija, veličina poduzeća, tehnologija, zadaci, ljudi, životni ciklus, lokacija i kultura poduzeća. Kao što je ranije spomenuto, unutarnji čimbenici su oni koji izviru iz samog poduzeća. Preciznije rečeno, to su čimbenici na koje poduzeće može izravno djelovati.

- Vanjski (egzogeni) čimbenici koji također određuju poduzeće, a samim time oblikovanje organizacijske strukture su oni koji ,izviru“ izvan organizacijskog rješenja, tj. oni koji nisu pod izravnom kontrolom menadžmenta poput okruženja, tržišta, 
institucionalnih uvjeta, konkurenata te razvoja znanosti i tehnologije. Potrebno je naglasiti kako prethodno spomenuti čimbenici nemaju podjednaku važnost u različitim situacijama, iako ih je sve potrebno uzeti u obzir prilikom razmatranja i optimiziranja prakse organizacijskog dizajna. Vanjski čimbenici organizacijske strukture se mogu podijeliti na institucionalne čimbenike (društveno-kulturni, politički, pravni i etički), tržišne (kupci, konkurencija, dobavljači), razvoj znanosti i tehnologije te integracijski procesi. Vanjski čimbenici su specifični po tome što se na njih ne može djelovati izravno odnosno poduzeće ne može na vanjske čimbenike djelovati jednako direktno i brzo kao na unutarnje čimbenike. Vanjski čimbenici su izvan poduzeća, iako nije nemoguće da poduzeće utječe i na te čimbenike.

$\mathrm{S}$ druge strane, u ovome radu će se prikazati i efikasnost poslovanja koja podrazumijeva odnos outputa prema inputima odnosno kako ostvariti maksimalni rezultat uz minimalno ulaganje i na taj način postići maksimalnu konkurentnost. Efikasnost i njeno praćenje je važno za poduzeća koja konkuriraju temeljem troškovne kompetitivnosti s ciljem povećanja profitabilnosti, proizvodnosti, prinosa, iskorištenja kapaciteta, korištenja obrtnih sredstava i korištenja proizvodnih sustava. Mjerenjem efikasnosti moguće je utvrditi iskorištenost resursa, a dobiveni rezultat stavlja se u odnos s inputima. Efikasnost mjeri konačni rezultat, a u obzir uzima uloženo i dobiveno, kako bi se ostvario postavljeni cilj. Stoga, efikasnost odgovara na pitanje koliko uspješno se koriste resursi (www.pbf.unizg.hr).

U pokazatelje efikasnosti se mogu ubrojiti brojni pokazatelji. Međutim, za potrebe istraživanja ovoga rada efikasnost poslovanja poduzeća će se mjeriti koristeći neto profitnu maržu, bruto profitnu maržu, rentabilnost ukupne imovine i rentabilnost vlastitog kapitala.

Neto profitna marža se izračunava na način da se neto dobit podijeli s ukupnim prihodom, a predstavlja udio neto dobiti u ukupnom prihodu. Bruto profitna marža se izračunava tako da se ostvarena dobit prije oporezivanja podijeli s ukupnim prihodom, a predstavlja udio bruto dobiti u ukupnom prihodu. Rentabilnost ukupne imovine odnosno povrat na imovinu (engl. Return Of Assets, ROA) se izračunava na način da se neto dobit odnosno gubitak podijeli s ukupnom aktivom. Rentabilnost vlastitog kapitala, tj. povrat na kapital (engl. Return Of Equity, ROE) se računa tako da se neto dobit odnosno gubitak podijeli s kapitalom i rezervama.

Nakon definiranja pojma organizacijske strukture i efikasnosti poslovanja, u ovome radu je moguće definirati predmet, problem, cilj, hipoteze i metode istraživanja. Predmet istraživanja u ovome radu je vezan uz ispitivanje utjecaja tipova organizacijske strukture na efikasnost poduzeća u prehrambenoj industriji Splitsko-dalmatinske županije, dok će se problemom istraživanja analizirati povezanost tipova organizacijske strukture s efikasnošću poduzeća u prehrambenoj industriji Splitsko-dalmatinske županije. Sukladno predmetu i problemu istraživanja, cilj istraživanja je utvrditi koji je tip organizacijske strukture primjeren poduzećima u prehrambenoj industriji Splitsko-dalmatinske županije kako bi se primjenom optimalnog tipa organizacijske strukture povećala njihova efikasnost. S obzirom da učinkovita implementacija primjerenog tipa organizacijske strukture u poduzećima omogućava brzu reakciju poduzeća na zahtjeve tržišta, u radu će se potvrditi ili opovrgnuti dvije temeljne hipoteze istraživanja i to:

H.1. Postoji statistički značajna razlika između primijenjenih tipova organizacijskih struktura i efikasnosti poduzeća. 
Dokazivanje odnosno odbacivanje glavne istraživačke hipoteze rada ispitat će se pomoću dvije pomoćne hipoteze rada i to:

H.1.1.: Postoji statistički značajna razlika između funkcijske i divizijske organizacijske strukture poduzeća s obzirom na efikasnost poslovanja poduzeća u prehrambenoj industriji Splitsko-dalmatinske županije.

U testiranju ove hipoteze polazi se od pretpostavke da će poduzeća s divizijskom organizacijskom strukturom imati veću efikasnost od poduzeća s funkcijskom organizacijskom strukturom.

H1.2.: Postoji statistički značajna razlika između divizijske i procesne organizacijske strukture poduzeća s obzirom na efikasnost poslovanja poduzeća u prehrambenoj industriji Splitsko-dalmatinske županije.

U testiranju ove hipoteze polazi se od pretpostavke da će poduzeća s procesnom organizacijskom strukturom imati veću efikasnost od poduzeća s divizijskom organizacijskom strukturom.

H.2.: Postoji statistički značajna razlika između faktora utjecaja na izbor organizacijske strukture i efikasnosti poduzeća u prehrambenoj industriji Splitsko-dalmatinske županije.

U testiranju ove hipoteze polazi se od pretpostavke da će poduzeća koja koriste strategiju, kao jedan od faktora utjecaja na izbor organizacijske strukture, imati veću efikasnost od poduzeća koja koriste okolinu prilikom izbora organizacijske strukture.

Empirijsko istraživanje će se provoditi primjenom uobičajenih znanstvenih metoda, a posebno metodom anketiranja i metodom obrade prikupljenih podataka primjenom statističkog paketa SPSS-a. Očekivani doprinos rada vezan je uz utvrđivanje tipa organizacijske strukture koji bi bio primjeren poduzećima u prehrambenoj industriji Splitsko-dalmatinske županije s ciljem povećanja njihove efikasnosti na domaćem i međunarodnim tržištima.

\section{PRETHODNA ISTRAŽIVANJA}

Organizacijska struktura je vrlo važan čimbenik u poslovanju poduzeća koju istražuju mnogi autori. Tako Zheng i suradnici (2010., str. 765-779.) istražuju međuzavisnost između organizacijskih struktura i organizacijske učinkovitosti. Rezultati istraživanja pokazali su značajne i negativne odnose prema rezultatima korelacijske analize. Nadalje, prema istome istraživanju organizacijska struktura standardiziranih procesa, zadataka i sustava u poduzeću utječe na organizacijsku učinkovitost. U ovome članku, u petoj hipotezi istraživanja ispituje se utjecaj organizacijske strukture na organizacijsku učinkovitost definirajući organizacijsku strukturu kao visokocentraliziranu. Prema tim rezultatima centralizirana organizacijska struktura negativno utječe na organizacijsku učinkovitost. Istraživanje je provedeno na uzorku od 301 poduzeća, od čega $28,7 \%$ su proizvodne tvrtke.

Ghani i suradnici (2002., str. 158-172.) ispituju tehnološki naprednu proizvodnju (engl. Advanced Manufacturing Technology, AMT) i značajke organizacijskih struktura kako bi se istražio utjecaj tehnološke opreme na organizacijsku strukturu, koristeći proizvodnost kao mjeru učinka poslovanja. Istraživanje je provedeno na uzorku od 65 velikih i 100 malih poduzeća koje su u proizvodnom procesu koristile AMT. Stopa odgovora bila je 
$16,36 \%$ (27 poduzeća), a rezultati istraživanja pokazali su značajnu i pozitivnu korelaciju (Spearmanov koeficijent korelacije) između organizacijskog indeksa koji uključuje organizacijsku strukturu i proizvodnosti u proizvodnim tvrtkama koje su primijenile napredna tehnološka dostignuća.

Gupta i suradnici (1997., str. 513-517.) istražili su utjecaj oblika organizacijske strukture na implementaciju AMT modela, mjereno na temelju učinkovitosti proizvodnje u pogledu vremena isporuke. Istraživanje je provedeno na uzorku od 101 proizvodnog poduzeća sa stopom povrata od 20,2 \%. Rezultati istraživanja su pokazali da specijalizacija i decentralizacija u donošenju odluka, kao dijelovi organizacijske strukture, imaju pozitivan utjecaj na poslovanje poduzeća te da visoka formalizacija organizacijske strukture smanjuje performanse poduzeća. Također je dokazano da poduzeća koja primjenjuju mehanicističku organizacijsku strukturu nisu toliko učinkovita u izvršenju zadataka.

Istraživanje Salaj-Ćetković (2009., str. 275.) nedvojbeno je pokazalo da postojanje odjela za planiranje u poduzećima ovisi o vrsti postojećih organizacijskih struktura. Rezultati su pokazali da odjel za planiranje postoji u $80 \%$ poduzeća s mješovitom organizacijskom strukturom, $70 \%$ poduzeća s divizijskom organizacijskom strukturom, $62 \%$ poduzeća s matričnom organizacijskom strukturom, $55 \%$ poduzeća s procesnom organizacijskom strukturom, $50 \%$ poduzeća s hibridnom organizacijskom strukturom, $41 \%$ poduzeća s funkcionalnom organizacijskom strukturom i $17 \%$ poduzeća s projektnom organizacijskom strukturom. Prema rezultatima istraživanja nema dokaza o postojanju odjela za planiranje u poduzećima u kojima se uspostavlja mrežna organizacijska struktura.

$\mathrm{Na}$ području organizacijske strukture i planiranja proizvodnje provedeno je mnogo istraživanja. U svome istraživanju Nahm i suradnici (2003., str. 290-297.) ispituju odnose između organizacijske strukture i vremenski definirane proizvodnje i postrojenja. Glavni cilj te studije bio je istražiti utjecaj organizacijske strukture proizvodnje na performanse postrojenja na način da je model definiran odnosom ove tri varijable. Za organizacijsku strukturu je važan utjecaj pojedinih elemenata kao što su stupanj formalizacije, broj hijerarhijskih razina, razina horizontalne integracije u vrijeme proizvodnje te plan izvedbe tvornice. Učinak postrojenja mjeren je stopom prodaje, povratom ulaganja, tržišnim udjelom i konkurentskoj poziciji u industriji te proizvodnosti. Istražili su i interakciju kohezije unutar elemenata organizacijske strukture kroz osam hipoteza, a u devetoj hipotezi istražili su utjecaj tipa proizvodnog ciklusa na performanse postrojenja. Istraživanje je provedeno nad 224 proizvodna poduzeća od ukupno 3000. Rezultati istraživanja su pokazali da je stupanj formalizacije, broj hijerarhijskih razina i stupanj horizontalne integracije kod odlučivanja i razina komunikacije u poduzećima imaju statistički značajan, pozitivan i izravan utjecaj na vremenski ciklus proizvodnje i performanse proizvodnog postrojenja.

Mateljak i Bilić (2012., str. 925-930.) u svome istraživanju ispituju povezanost između tipa organizacijske strukture i organizacijskih performansi na primjeru poduzeća u Republici Hrvatskoj u vremenskom razdoblju od 2007. do 2011. godine. Što se tiče organizacijske strukture u radu je korišteno pet tipova, i to funkcijska, divizijska, matrična, procesna i mrežna. S druge strane, prilikom ispitivanja organizacijskih performansi korišteni su ukupni prihod, profit, neto profitna marža i prosječni broj zaposlenika. Istraživanje je provedeno nad 70 hrvatskih poduzeća. Rezultati istraživanja su pokazali da najveći prihod imaju poduzeća s divizijskom organizacijskom strukturom, najveći profit ostvaruju poduzeća s divizijskom organizacijskom strukturom, najveću stopu neto profitne marže imaju 
poduzeća s mrežnom organizacijskom strukturom, dok najveći prosječni rast broja zaposlenika imaju poduzeća s funkcijskom organizacijskom strukturom. Ono što je posebno bitno navesti u ovome istraživanju je da funkcijsku organizacijsku strukturu najviše koriste poduzeća u proizvodnji hrane, divizijsku organizacijsku strukturu poduzeća u poslovnom konzaltingu, matričnu organizacijsku strukturu poduzeća u građevinarstvu, procesnu organizacijsku strukturu poduzeća u izdavaštvu, dok mrežnu organizacijsku strukturu poduzeća u dodatnim uslugama u transportu. Nadalje, u istraživanju se također došlo do podataka da funkcijsku organizacijsku strukturu poduzeća s prosječnom starosti od 55 godina, divizijsku organizacijsku strukturu poduzeća s prosječnom starosti od 66 godina, matričnu organizacijsku strukturu poduzeća s prosječnom starosti od 40 godina, procesnu organizacijsku strukturu poduzeća s prosječnom starosti od 20 godina, dok mrežnu organizacijsku strukturu poduzeća s prosječnom starosti od 37 godina.

\section{REZULTATI ISTRAŽIVANJA}

\subsection{Metodologija istraživanja}

Istraživanje utjecaja primijenjenih tipova organizacijskih struktura na efikasnost poduzeća u prehrambenoj industriji Splitsko-dalmatinske županije provedeno je metodom anketiranja u kolovozu 2017. godine na području spomenute Splitsko-dalmatinske županije.

Ispitanici su prije pristupa anketnom upitniku informirani o tome da se istraživanje provodi za potrebe izrade članka, da će ispunjavanje trajati oko dvadeset minuta te da će ispunjavanjem upitnika ispitanici doprinijeti utvrđivanju međuzavisnosti između primijenjenih tipova organizacijske strukture i efikasnosti poduzeća u prehrambenoj industriji u Splitsko-dalmatinskoj županiji.

U provođenju anketiranja, bilo je važno da se prije pristupanja ispunjavanju upitnika ispitanici informiraju da su njihovi odgovori anonimni, da će se koristiti isključivo za izradu empirijskog dijela ovoga rada te im je posebno istaknuto da će se njihovi odgovori koristiti u svrhu ispitivanja postojanosti međuzavisnosti između primijenjenih tipova organizacijske strukture i efikasnosti poduzeća, identificiranju problema koji se pojavljuju prilikom organiziranja poslovanja poduzeća te davanju prijedloga za rješavanje problema koji se pritom pojavljuju. Upitnik se sastojao od tri dijela i to:

- osnovni podaci o poduzeću

- identifikacija primijenjenog oblika organizacijske strukture

- utvrđivanje efikasnosti poduzeća.

Za istraživanje je korišten slučajan uzorak od 37 malih, srednjih i velikih poduzeća u prehrambenoj industriji Splitsko-dalmatinske županije. Stopa povrata iznosila je $100 \%$.

\subsection{Karakteristike uzorka}

Kao što je prethodno navedeno, ispunjavanju upitnika pristupilo je 37 ispitanika koji su voditelji proizvodnje i menadžeri u poduzećima u prehrambenoj industriji Splitsko-dalmatinske županije. Posebno je bitno naglasiti da je u istraživanju sudjelovalo 75,7 \% ili 28 
malih poduzeća, 18,9 \% ili 7 srednjih poduzeća i 5,4 \% i 2 velika poduzeća. Vrijednost Cronbach alfa testa pouzdanosti je 0,721. Strukturu ispitanika prema djelatnostima prehrambene industrije prikazuje slika 1.

Najveći broj ispitanika (njih 37,84 \%) je označilo djelatnost proizvodnje kruha. 16,22 $\%$ ispitanika posluje u djelatnosti prerade i konzerviranja mesa te u djelatnosti ostale prerade. Četvero ispitanika ili $10,81 \%$ obavlja svoje poslovanje u djelatnosti proizvodnje ulja i masti. Najmanji broj ispitanika $(2,7 \%)$ posluje u djelatnosti proizvodnje sokova.

Uz djelatnost, u istraživanju je također utvrđena i struktura ispitanika prema pravnom obliku. Istraživanjem je utvrđeno da 97,3 \% ispitanika ima pravni oblik dioničkoga društva s ograničenom odgovornošću (d.o.o.), dok samo $2,7 \%$ posluje u pravnom obliku trgovca pojedinca. Upitnik nije ispunio niti jedan ispitanik koji radi u poduzeću pravnog oblika kao dioničko društvo (d.d.).

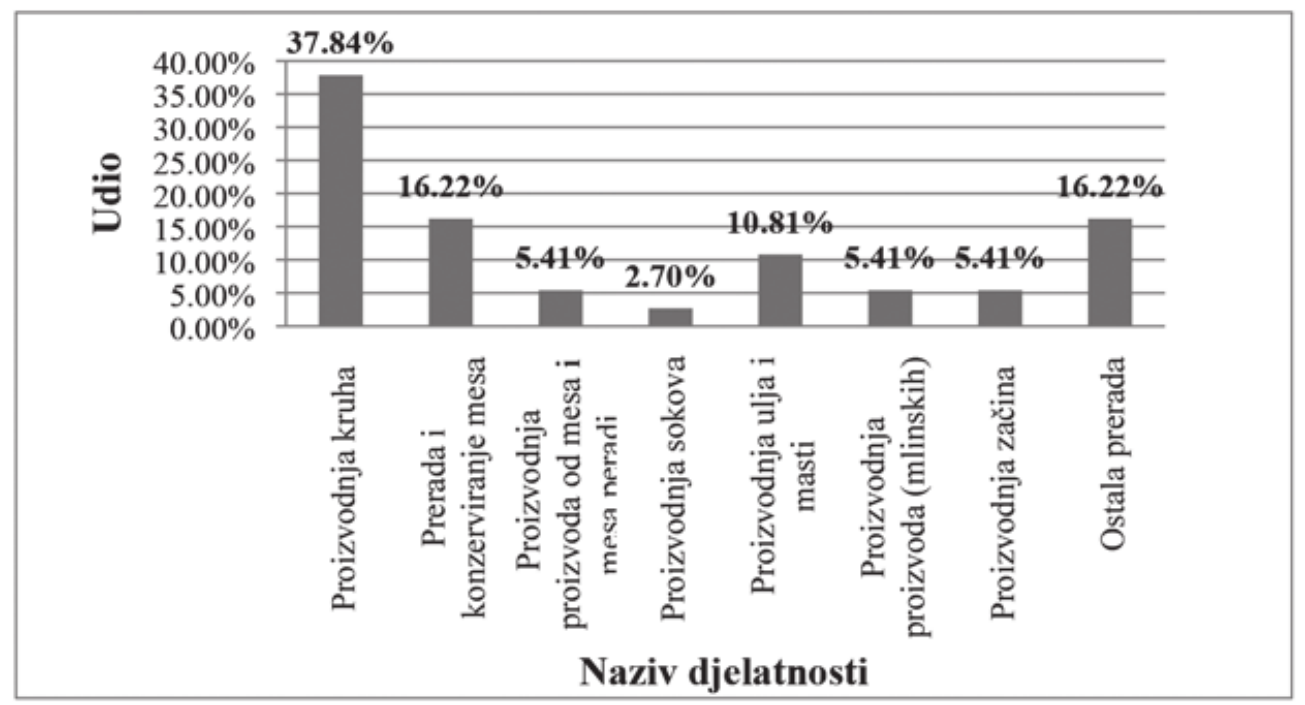

Slika 1. Djelatnosti ispitanika u prehrambenoj industriji

Izvor: izradili autori temeljem provedenoga istraživanja.

Nadalje, provođenjem anketnog istraživanja također je utvrđena i vlasnička struktura ispitanika u prehrambenoj industriji Splitsko-dalmatinske županije. Rezultati su pokazali da $97,3 \%$ ispitanika ima domaće privatno vlasništvo, dok ostatak ispitanika $(2,7 \%)$ imaju mješovito vlasništvo. Obzirom da je riječ o društvima s ograničenom odgovornošću koja su pretežito u domaćem privatnom vlasništvu, ovim istraživanjem se može zaključiti da u prehrambenoj industriji Splitsko-dalmatinske županije nema niti jedno poduzeće koje ima inozemno privatno vlasništvo, državno vlasništvo te vlasništvo zasnovano na radničkom dioničarstvu.

Uz vlasničku strukturu, prilikom istraživanja također je utvrđeno koji oblik organizacijske strukture imaju anketirana poduzeća što je prikazano na slici 2. 


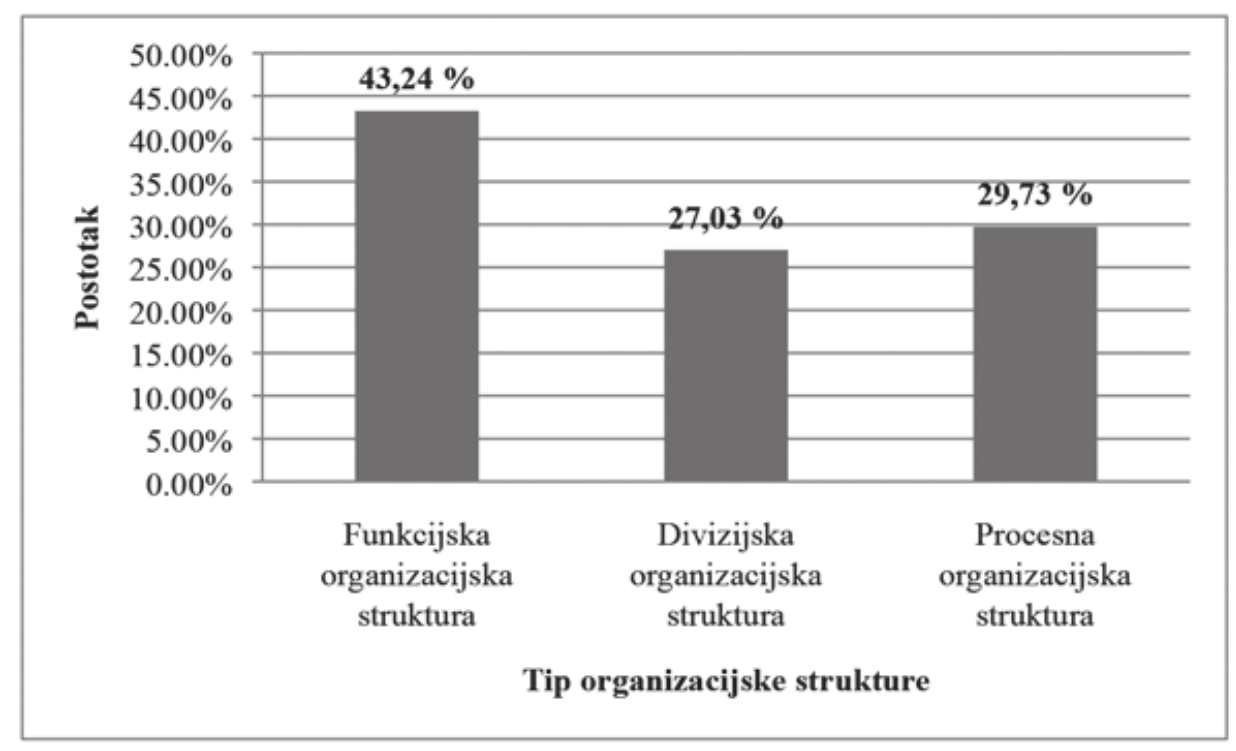

Slika 2. Tip organizacijske strukture

Izvor: izradili autori temeljem provedenoga istraživanja.

Kao što prikazuje slika 2. najveći broj anketiranih poduzeća, 16 ili 43,24 \%, imaju funkcijski oblik organizacijske strukture, 11 anketiranih poduzeća ili 29,73\% ima procesni oblik organizacijske strukture, dok 10 poduzeća ili 27,03 \% ima divizijski oblik organizacijske strukture. U prehrambenoj industriji Splitsko-dalmatinske županije ne postoje poduzeća koja imaju matrični i mrežni oblik organizacijske strukture.

Što se tiče tipa proizvodnog procesa, istraživanje je pokazalo da poduzeća imaju dva tipa proizvodnog procesa i to $86,5 \%$ ispitanih poduzeća imaju prekidani tip proizvodnog procesa, dok 13,5 \% poduzeća imaju linijski tip proizvodnog procesa. Istraživanjem je također utvrđeno da niti jedno od anketiranih poduzeća u prehrambenoj industriji Splitsko-dalmatinske županije nema projektni tip proizvodnog procesa, što je i očekivano budući da je riječ o prehrambenoj industriji.

U nastavku rada istraživanjem će se identificirati određeni faktori koji najčešće utječu na promjenu organizacijske strukture anketiranih poduzeća u prehrambenoj industriji Splitsko-dalmatinske županije. U te faktore spadaju: tržište, ciljevi, strategija, tehnologija, zadaci, ljudi i lokacija. Prethodno navedeni faktori koje su ispitanici u istraživanju naveli prikazani su na slici 3.

Sa slike 3. vidi se da je 45,95 \% anketiranih poduzeća navelo da je tržište temeljni faktor koji utječe na promjenu tipa organizacijske strukture. Uz tržište, kod 13,51 \% anketiranih poduzeća glavni faktor koji utječe na promjenu tipa organizacijske strukture su tehnologija i strategija, dok je kod 10,81 \% lokacija. Kod najmanjeg broja anketiranih poduzeća, točnije $8,11 \%$ je navelo ciljeve koji uzrokuju promjenu tipa organizacijske strukture, 5,41 $\%$ je navelo ljude te $2,7 \%$ je navelo postavljene zadatke. 


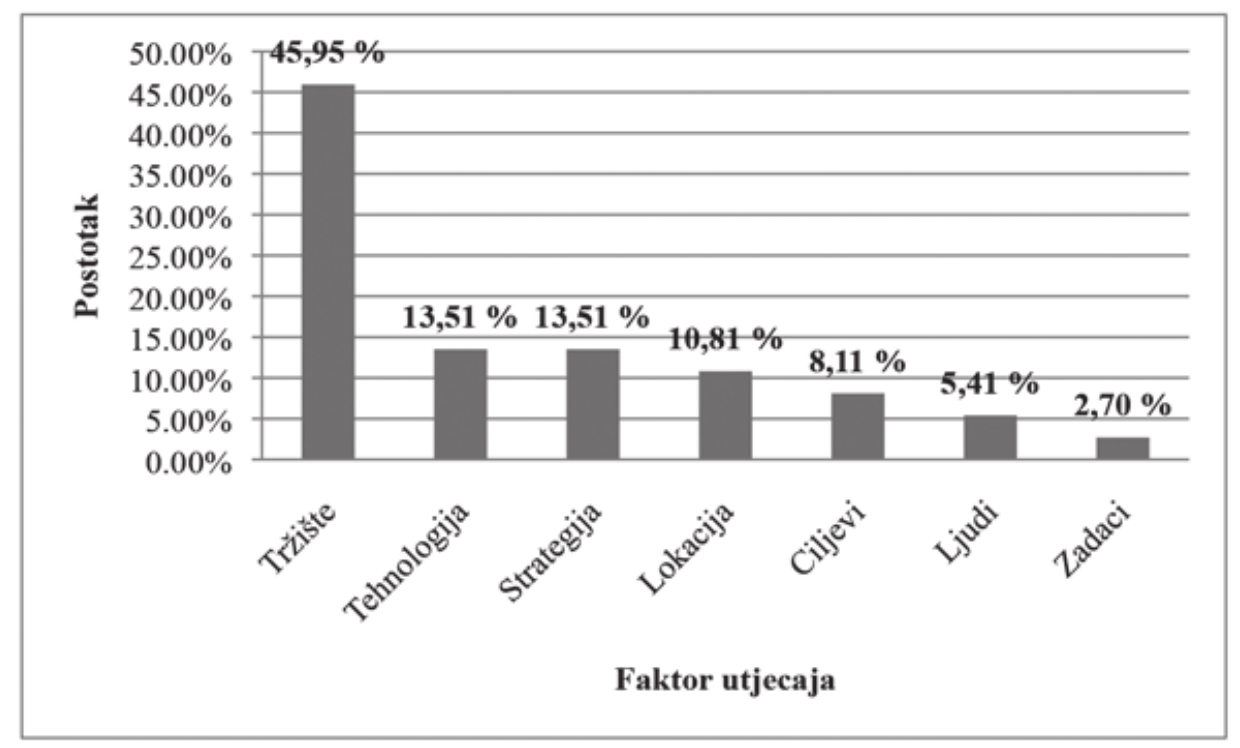

Slika 3. Faktori utjecaja na promjenu tipa organizacijske strukture

Izvor: izradili autori temeljem provedenoga istraživanja.

Nakon utvrđivanja temeljnih faktora koji utječu na promjenu organizacijske strukture, prikazat će se koliko promjena veličine poduzeća, okolina, strategija i tehnologija određuju tip organizacijske strukture kod anketiranih poduzeća u prehrambenoj industriji Splitsko-dalmatinske županije. Razlog pojedinačnog prikazivanja ova četiri faktora koja utječu na promjenu organizacijske strukture je u činjenici da sva relevantna literatura iz područja organizacije poslovanja upravo navodi ova četiri faktora kao temeljna. U ovome tipu istraživanja korištena je skala od 1 do 5 , gdje $1=$ nimalo, $2=$ vrlo malo, $3=$ djelomično, $4=$ mnogo, $5=$ u cijelosti. Slikom 4. prikazani su rezultati istraživanja u kojem stupnju veličina poduzeća potiče poduzeće na oblikovanje organizacijske strukture.

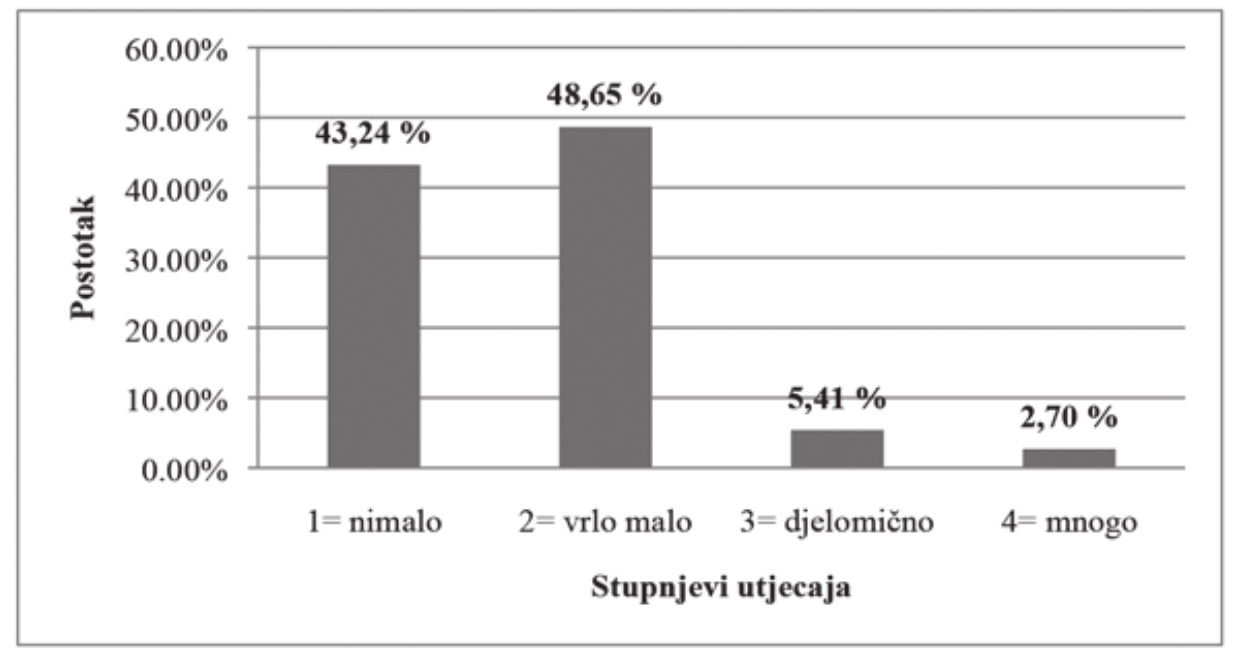

Slika 4. Veličina poduzeća kao uzrok promjene organizacijske strukture 
Kao što prikazuje slika 4., 48,65 \% poduzeća smatra da veličina poduzeća vrlo malo utječe na promjenu organizacijske strukture, dok 43,24 \% poduzeća smatra da veličina poduzeća nimalo ne utječe na promjenu organizacijske strukture. Budući da ova dva odgovora spadaju u područje vrlo malog utjecaja veličine poduzeća na promjenu organizacijske strukture, može se zaključiti da kod gotovo 91,89 \% poduzeća veličina poduzeća nije faktor zbog kojega bi se oblikovala organizacijska struktura.

Kao što je prethodno navedeno, uz veličinu poduzeća, drugi važan faktor koji utječe na oblikovanje organizacijske strukture je okolina odnosno poslovno okruženje. Rezultati istraživanja su prikazani na slici 5.

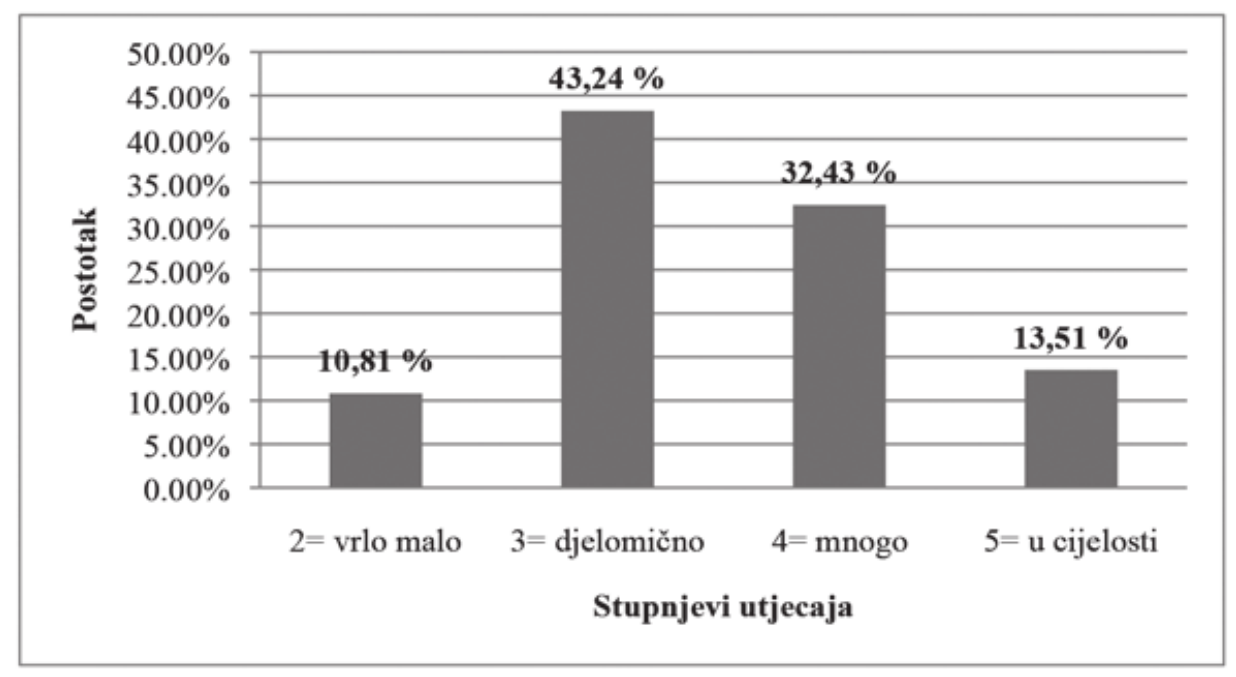

Slika 5. Okolina poduzeća kao uzrok promjene organizacijske strukture

Izvor: izradili autori temeljem provedenoga istraživanja.

Sa slike 5. vidi se da 43,24\% anketiranih poduzeća smatra da okolina djelomično utječe na oblikovanje organizacijske strukture, 32,43\% anketiranih poduzeća smatra da okolina mnogo utječe na promjenu organizacijske strukture, dok 13,51\% smatra da okolina u cijelosti utječe na promjenu organizacijske strukture. Kada se ovi rezultati istraživanja još detaljnije analiziraju, može se zaključiti da $89,18 \%$ anketiranih poduzeća smatra da je okolina vrlo važan čimbenik utjecaja na promjenu organizacijske strukture kod poduzeća u prehrambenoj industriji Splitsko-dalmatinske županije. Bitno je naglasiti da samo 10,81\% poduzeća smatra da okolina vrlo malo utječe na promjenu organizacijske strukture.

Uz veličinu poduzeća i okolinu, treći faktor koji utječe na promjenu organizacijske strukture je strategija. Rezultati istraživanja za ovaj faktor utjecaja su prikazani na slici 6 .

Slika 6. prikazuje da 45,95\% anketiranih poduzeća smatra da strategija mnogo utječe na oblikovanje organizacijske strukture, $40,54 \%$ anketiranih poduzeća smatra da strategija djelomično utječe na promjenu organizacijske strukture, dok 8,11 \% smatra da strategija u cijelosti utječe na promjenu organizacijske strukture. 


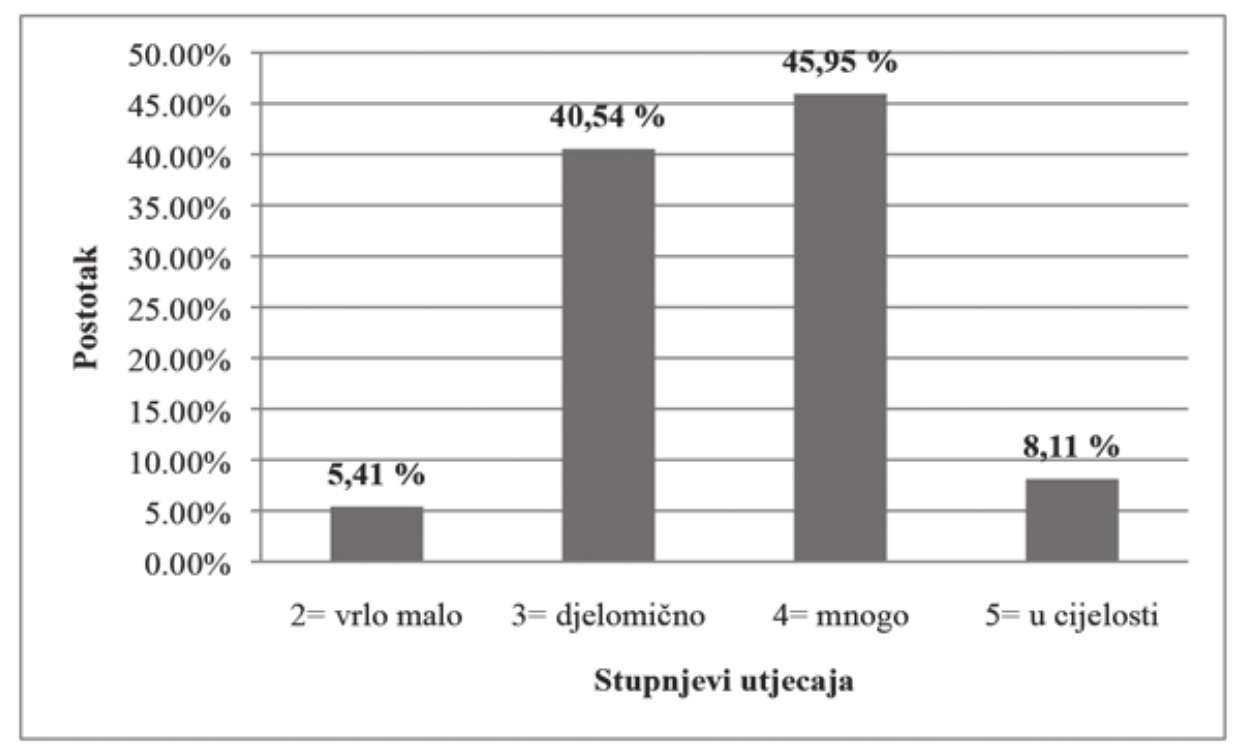

Slika 6. Strategija kao uzrok promjene organizacijske strukture

Izvor: izradili autori temeljem provedenoga istraživanja.

Kada se ovi rezultati istraživanja još detaljnije analiziraju, može se zaključiti da 94,59 $\%$ anketiranih poduzeća smatra da je strategija ključan čimbenik utjecaja na promjenu organizacijske strukture kod poduzeća u prehrambenoj industriji Splitsko-dalmatinske županije. Bitno je naglasiti da samo 5,41 \% poduzeća smatra da strategija vrlo malo utječe na promjenu organizacijske strukture.

S obzirom da u malim, a često i u srednjim poduzećima nije primjerena divizijska organizacijska struktura, utjecaj okoline i strategije na oblikovanje organizacijske strukture nikako nije isključiv, pa poduzeća moraju definitivno voditi računa o oba čimbenika.

Četvrti faktor koji utječe na promjenu organizacijske strukture je tehnologija. Jačinu utjecaja tehnologije na promjenu organizacijske strukture prikazuje slika 7.

Kao što prikazuje slika 7., 35,14 \% anketiranih poduzeća smatra da tehnologija mnogo utječe na oblikovanje organizacijske strukture, 27,03 \% anketiranih poduzeća smatra da tehnologija djelomično utječe na promjenu organizacijske strukture, dok 8,11\% smatra da tehnologija u cijelosti utječe na promjenu organizacijske strukture. Kada se ovi rezultati istraživanja još detaljnije analiziraju, može se zaključiti da 70,28 \% anketiranih poduzeća smatra da je tehnologija ključan čimbenik utjecaja na promjenu organizacijske strukture kod poduzeća u prehrambenoj industriji Splitsko-dalmatinske županije. Za razliku od rezultata istraživanja kod prethodnih faktora, bitno je naglasiti da $24,32 \%$ poduzeća smatra da tehnologija vrlo malo utječe na promjenu organizacijske strukture te da 5,41\% poduzeća smatra da tehnologija nimalo utječe na promjenu organizacijske strukture. To znači da $29,72 \%$ poduzeća smatra da tehnologija nije bitan faktor prilikom promjene organizacijske strukture.

Kada se analiziraju rezultati istraživanja za prethodno navedena četiri faktora koji utječu na promjenu organizacijske strukture, može se zaključiti da su anketirana poduzeća navela da strategija $(94,16 \%)$ najviše utječe na promjenu organizacijske strukture, dok tehnologija $(70,28 \%)$ najmanje utječe na promjenu organizacijske strukture. Jedini faktor 
kojega su anketirana poduzeća navela da nema utjecaj na promjenu organizacijske strukture je veličina poduzeća $(91,89 \%)$.

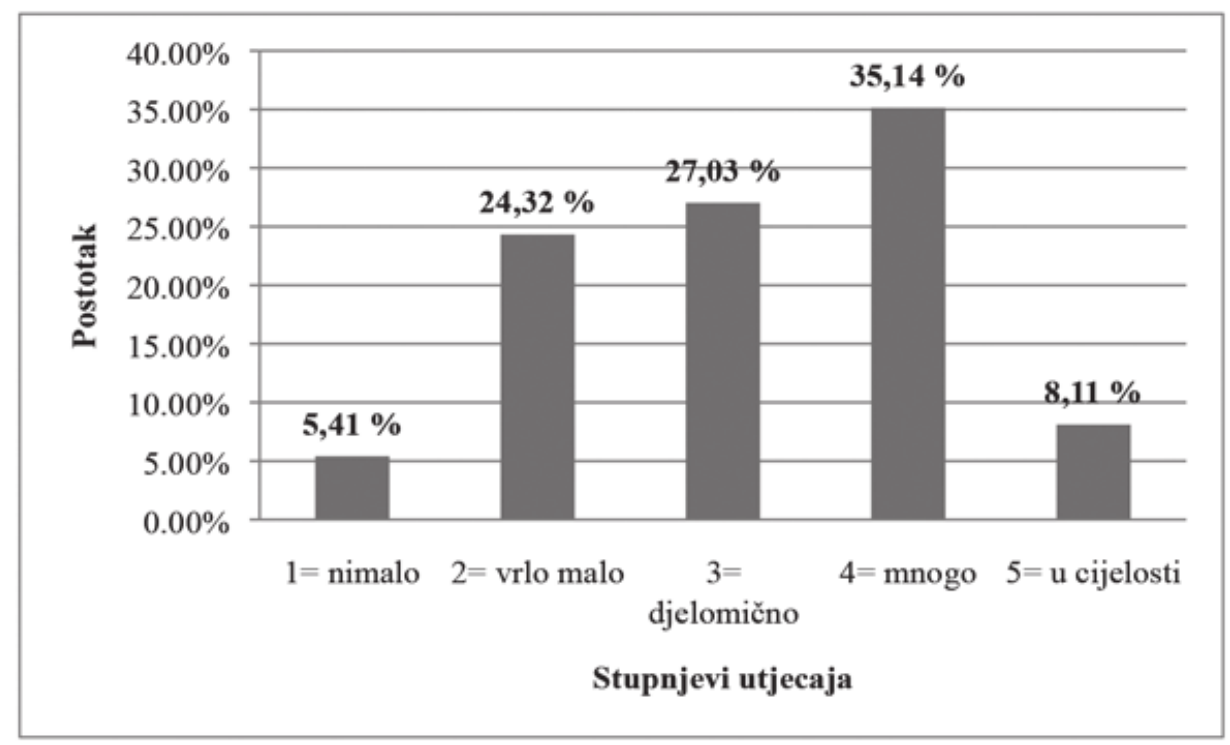

Slika 7. Tehnologija kao uzrok promjene organizacijske strukture

Izvor: izradili autori temeljem provedenoga istraživanja.

Nakon analiziranja prethodno navedenih rezultata istraživanja, u nastavku rada prikazat će se rezultati istraživanja temeljem kojih će se prihvatiti ili odbaciti postavljene istraživačke hipoteze.

\subsection{Testiranje istraživačkih hipoteza}

Temeljem prikupljenih podataka metodom anketnog upitnika testirat će se temeljne istraživačke hipoteze rada koristeći analizom varijance (ANOVA). Obradom prikupljenih podataka dat će se odgovor na dvije postavljene temeljne istraživačke hipoteze rada i to:

H.1. Postoji statistički značajna razlika između primijenjenih tipova organizacijskih struktura i efikasnosti poduzeća.

Dokazivanje odnosno odbacivanje glavne istraživačke hipoteze rada ispitat će se pomoću dvije pomoćne hipoteze rada i to:

H.1.1.: Postoji statistički značajna razlika između funkcijske i divizijske organizacijske strukture poduzeća s obzirom na efikasnost poslovanja poduzeća u prehrambenoj industriji Splitsko-dalmatinske županije.

U testiranju ove hipoteze polazi se od pretpostavke da će poduzeća s divizijskom organizacijskom strukturom imati veću efikasnost od poduzeća s funkcijskom organizacijskom strukturom.

H.1.2.: Postoji statistički značajna razlika između divizijske i procesne organizacijske strukture poduzeća s obzirom na efikasnost poslovanja poduzeća u prehrambenoj industriji Splitsko-dalmatinske županije. 
U testiranju ove hipoteze polazi se od pretpostavke da će poduzeća s procesnom organizacijskom strukturom imati veću efikasnost od poduzeća s divizijskom organizacijskom strukturom.

H.2.: Postoji statistički značajna razlika između faktora utjecaja na izbor organizacijske strukture i efikasnosti poduzeća u prehrambenoj industriji Splitsko-dalmatinske županije.

U testiranju ove hipoteze polazi se od pretpostavke da će poduzeća koja koriste strategiju, kao jedan od faktora utjecaja na izbor organizacijske strukture, imati veću efikasnost od poduzeća koja koriste okolinu prilikom izbora organizacijske strukture.

U radu će se najprije prikazati rezultati istraživanja za prvu temeljnu istraživačku hipotezu. Budući da se prva temeljna istraživačka hipoteza ispituje putem dvije pomoćne istraživačke hipoteze, najprije će se prikazati rezultati istraživanja za prvu pomoćnu istraživačku hipotezu. Temeljem dobivenih rezultata istraživanja utvrdit će se postojanost statistički značajne razlike između funkcijske i divizijske organizacijske strukture poduzeća s obzirom na efikasnost poslovanja poduzeća u prehrambenoj industriji Splitsko-dalmatinske županije. Rezultati istraživanja prikazani su u tablici 1.

Tablica 1. Testiranje statistički značajne razlike između funkcijske i divizijske organizacijske strukture s obzirom na efikasnost poslovanja poduzeća u prehrambenoj industriji Splitsko-dalmatinske županije

\begin{tabular}{|c|c|c|c|c|}
\hline \multirow{2}{*}{$\begin{array}{c}\text { Oblik } \\
\text { organizacijske } \\
\text { strukture }\end{array}$} & \multicolumn{4}{|c|}{ PROSJEČNA VRIJEDNOST POKAZATELJA EFIKASNOSTI } \\
\cline { 2 - 5 } & $\begin{array}{c}\text { Neto } \\
\text { profitna } \\
\text { marža }\end{array}$ & $\begin{array}{c}\text { Bruto } \\
\text { profitna } \\
\text { marža }\end{array}$ & $\begin{array}{c}\text { Stopa povrata na } \\
\text { ukupnu imovinu } \\
\text { (engl. ROA) }\end{array}$ & $\begin{array}{c}\text { Stopa povrata na } \\
\text { vlastiti kapital (engl. } \\
\text { ROE) }\end{array}$ \\
\hline Funkcijska & $3,6 \%$ & $4,13 \%$ & $7,88 \%$ & $4,06 \%$ \\
\hline Divizijska & $2,03 \%$ & $3 \%$ & $6,02 \%$ & $8,38 \%$ \\
\hline p- vrijednost & 0,449502 & 0,633410 & 0,679683 & 0,431285 \\
\hline
\end{tabular}

Izvor: izradili autori temeljem provedenoga istraživanja.

Temeljem dobivenih rezultata istraživanja iz tablice 1. može se zaključiti da poduzeća koja imaju funkcijsku organizacijsku strukturu imaju veću efikasnost poslovanja od poduzeća koja imaju divizijsku organizacijsku strukturu kod tri pokazatelja i to kod neto profitne marže (3,6 \% naspram $2,03 \%)$, bruto profitne marže $(4,13 \%$ naspram $3 \%)$ i stope povrata na ukupnu imovinu (ROA) (7,88 \% naspram 6,02 \%). Poduzeća koja imaju divizijsku organizacijsku strukturu imaju veću efikasnost poslovanja od poduzeća koja imaju funkcijsku organizacijsku strukturu kod jednog pokazatelja i to kod stope povrata na vlastiti kapital (ROE) $(8,38 \%$ naspram 4,06 \%). Statistička značajnost prethodno analiziranih rezultata istraživanja ispitana je na razini signifikantnosti testa od $10 \%$. Kao što se vidi iz tablice 1., niti jedna od četiri vrijednosti statističke značajnosti nije manja od $10 \%$. Temeljem toga može se zaključiti da ne postoji statistički značajna razlika između funkcijske i divizijske organizacijske strukture s obzirom na efikasnost poslovanja poduzeća u prehrambenoj industriji Splitsko-dalmatinske županije čime se prva pomoćna istraživačka hipoteza ne prihvaća.

Nakon neprihvaćanja prve pomoćne istraživačke hipoteze, u nastavku rada prikazat će se rezultati istraživanja za drugu pomoćnu istraživačku hipotezu rada kojom se ispi- 
tuje postojanost statistički značajne razlike između divizijske i procesne organizacijske strukture poduzeća s obzirom na efikasnost poslovanja poduzeća u prehrambenoj industriji Splitsko-dalmatinske županije. Rezultate testiranja druge pomoćne istraživačke hipoteze prikazuje tablica 2.

Tablica 2. Testiranje statistički značajne razlike između divizijske i procesne organizacijske strukture s obzirom na efikasnost poslovanja poduzeća u prehrambenoj industriji Splitsko-dalmatinske županije

\begin{tabular}{|c|c|c|c|c|}
\hline \multirow{2}{*}{$\begin{array}{c}\text { Oblik } \\
\text { organizacijske } \\
\text { strukture }\end{array}$} & \multicolumn{4}{|c|}{ PROSJEČNA VRIJEDNOST POKAZATELJA EFIKASNOSTI } \\
\cline { 2 - 5 } & $\begin{array}{c}\text { Neto } \\
\text { profitna } \\
\text { marža }\end{array}$ & $\begin{array}{c}\text { Bruto } \\
\text { profitna } \\
\text { marža }\end{array}$ & $\begin{array}{c}\text { Stopa povrata na } \\
\text { ukupnu imovinu } \\
\text { (engl. ROA) }\end{array}$ & $\begin{array}{c}\text { Stopa povrata na } \\
\text { vlastiti kapital (engl. } \\
\text { ROE) }\end{array}$ \\
\hline Divizijska & $2,03 \%$ & $3 \%$ & $6,02 \%$ & $8,38 \%$ \\
\hline Procesna & $3,34 \%$ & $4,23 \%$ & $3,26 \%$ & $3,56 \%$ \\
\hline p- vrijednost & $0,069346^{*}$ & $0,037107 *$ & $0,025574^{*}$ & $0,015144^{*}$ \\
\hline
\end{tabular}

Izvor: izradili autori temeljem provedenoga istraživanja.

* Signifikantnost testa na razini od $10 \%$.

Kao što se vidi iz tablice 2. poduzeća koja imaju divizijsku organizacijsku strukturu imaju veću efikasnost poslovanja od poduzeća koja imaju procesnu organizacijsku strukturu kod dva pokazatelja i to kod stope povrata na ukupnu imovinu (ROA) $(6,02 \%$ naspram $3,26 \%)$ i stope povrata na vlastiti kapital (ROE) (8,38 \% naspram 3,56 \%). Kod ova dva pokazatelja bitno je naglasiti da postoji statistički značajna razlika između divizijske i procesne organizacijske strukture na razini signifikantnosti od $10 \%(p=0,025574, p<0,1$ i p $=0,015144, \mathrm{p}<0,1)$ čime se potvrđuje prethodno analizirani rezultat istraživanja. $\mathrm{S}$ druge strane, poduzeća koja imaju procesnu organizacijsku strukturu imaju veću efikasnost poslovanja od poduzeća koja imaju divizijsku organizacijsku strukturu kod dva pokazatelja i to kod neto profitne marže $(3,34 \%$ naspram $2,03 \%)$ i bruto profitne marže $(4,23 \%$ naspram 3 $\%)$. Iz dobivenih rezultata se vidi da postoji statistički značajna razlika između divizijske i procesne organizacijske strukture kod oba pokazatelja $(\mathrm{p}=0,069346, \mathrm{p}<0,1$ i $\mathrm{p}=0,037107$, $\mathrm{p}<0,1)$ čime se potvrđuje prethodno navedeni rezultat istraživanja. Iz prethodno navedenih rezultata istraživanja može se zaključiti da je druga pomoćna istraživačka hipoteza djelomično prihvaćena.

Nakon analiziranja rezultata istraživanja prve i druge pomoćne istraživačke hipoteze rada utvrđuje se da prva temeljna hipoteza rada nije potvrđena.

Prilikom testiranja druge temeljne istraživačke hipoteze rada ispituje se postojanost statistički značajne razlike između faktora utjecaja na izbor organizacijske strukture i efikasnosti poslovanja poduzeća u prehrambenoj industriji Splitsko-dalmatinske županije. Kao što je prethodno analizirano, na promjenu organizacijske strukture kod anketiranih poduzeća u prehrambenoj industriji Splitsko-dalmatinske županije utječu četiri faktora i to veličina poduzeća, okolina, strategija i tehnologija. Budući da je istraživanje pokazalo da od četiri faktora, na promjenu organizacijske strukture najviše utječu strategija (kod 94,16 $\%$ anketiranih poduzeća) i okolina (kod 89,18 \% anketiranih poduzeća) koji su ujedno i najznačajniji izvori konkurentnosti poduzeća u ovome tipu industrije, u testiranju ove istra- 
Živačke hipoteze polazi se od pretpostavke da će poduzeća koja koriste strategiju, kao jedan od faktora utjecaja na izbor organizacijske strukture, imati veću efikasnost od poduzeća koja koriste okolinu prilikom izbora organizacijske strukture. Dobiveni rezultati istraživanja prikazani su u tablici 3.

Tablica 3. Testiranje statistički značajne razlike između faktora utjecaja na izbor organizacijske strukture i efikasnosti

\begin{tabular}{|c|c|c|c|c|}
\hline $\begin{array}{c}\text { Faktor utjecaja } \\
\text { na izbor } \\
\text { organizacijske } \\
\text { strukture }\end{array}$ & \multicolumn{4}{|c|}{ PROSJEČNA VRIJEDNOST POKAZATELJA } \\
\cline { 2 - 5 } & $\begin{array}{c}\text { Neto } \\
\text { profitna } \\
\text { marža }\end{array}$ & $\begin{array}{c}\text { Bruto } \\
\text { profitna } \\
\text { marža }\end{array}$ & $\begin{array}{c}\text { Stopa povrata na } \\
\text { ukupnu imovinu } \\
\text { (engl. ROA) }\end{array}$ & $\begin{array}{c}\text { Stopa povrata na } \\
\text { vlastiti kapital } \\
\text { (engl. ROE) }\end{array}$ \\
\hline Okolina & $3,17 \%$ & $3,95 \%$ & $6,10 \%$ & $14,61 \%$ \\
\hline Strategija & $6,70 \%$ & $7,89 \%$ & $8,35 \%$ & $15,58 \%$ \\
\hline p- vrijednost & $0,010140 *$ & $0,000617 *$ & $0,077029 *$ & $0,062047 *$ \\
\hline
\end{tabular}

Izvor: izradili autori temeljem provedenoga istraživanja.

* Signifikantnost testa na razini od $10 \%$.

Iz tablice 3. može se zaključiti da poduzeća koja koriste strategiju, kao faktor izbora organizacijske strukture, imaju veću efikasnost poslovanja od poduzeća koja koriste okolinu prilikom izbora organizacijske strukture kod sva četiri pokazatelja i to kod neto profitne marže $(6,70 \%$ naspram $3,17 \%)$, bruto profitne marže $(7,89 \%$ naspram $3,95 \%)$, stope povrata na ukupnu imovinu $(8,35 \%$ naspram $6,10 \%)$ i stope povrata na vlastiti kapital $(15,58$ $\%$ naspram 14,61 \%). Statistička značajnost prethodno analiziranih rezultata istraživanja ispitana je na razini signifikantnosti testa od $10 \%$. Kao što se vidi iz tablice 3., sve vrijednosti statističke značajnosti su manje od $10 \%(\mathrm{p}=0,010140, \mathrm{p}<0,1 ; \mathrm{p}=0,000617, \mathrm{p}<0,1$; $\mathrm{p}=0,077029, \mathrm{p}<0,1 \mathrm{i} \mathrm{p}=0,062047, \mathrm{p}<0,1)$. Temeljem takvih rezultata istraživanja može se zaključiti da postoji statistički značajna razlika između poduzeća koja koriste strategiju, kao jedan od faktora utjecaja na izbor organizacijske strukture i poduzeća koja koriste okolinu prilikom izbora organizacijske strukture. Točnije, poduzeća koja koriste strategiju kao faktor izbora organizacijske strukture postižu veću efikasnost od poduzeća koja koriste okolinu kao faktor izbora organizacijske strukture čime je druga temeljna istraživačka hipoteza potvrđena.

\section{ZAKLJUČAK}

Jedan od važnijih čimbenika koji utječe na organizacijsku strukturu je industrija kao vanjski čimbenik, koji utječe na izbor, oblikovanje i učestalost promjena nad organizacijskom strukturom poduzeća. Ovisno o industriji u kojoj poduzeće posluje, ono može odabrati klasičnu ili modernu organizacijsku strukturu. Prilikom izbora organizacijske strukture treba obratiti pozornost i na sljedeće elemente: veličinu poduzeća, strategiju, okolinu i tehnologiju. 
Poduzeća se prilikom oblikovanja organizacijske strukture fokusiraju i na izbor one organizacijske strukture koja će najviše doprinijeti povećanju profitabilnosti, produktivnosti, ekonomičnosti i efikasnosti poslovanja. Od navedenih, efikasnost je važna za poduzeća koja konkuriraju ili moraju konkurirati temeljem troškovne kompetitivnosti, kao što je primjerice prehrambena industrija.

U Splitsko-dalmatinskoj županiji u prehrambenoj industriji u pravilu posluju mala i srednja poduzeća koja posluju kao društvo s ograničenom odgovornošću te koja koriste funkcijsku, procesnu i divizijsku organizacijsku strukturu, a pritom se zbog okolnosti tržišta na kojemu posluju više fokusiraju na organizacijsku strukturu koja će povećati samu efikasnost. Temeljem rezultata istraživanja utvrđeno je da ne postoji statistički značajna razlika između tipova organizacijskih struktura i efikasnosti poduzeća u prehrambenoj industriji. Točnije, ne postoji statistički značajna razlika između funkcijske i divizijske organizacijske strukture poduzeća s obzirom na efikasnost poslovanja poduzeća u prehrambenoj industriji Splitsko-dalmatinske županije.

Isto tako, istraživanje je pokazalo da postoji statistički značajna razlika između divizijske i procesne organizacijske strukture poduzeća s obzirom na efikasnost poslovanja poduzeća u prehrambenoj industriji Splitsko-dalmatinske županije. Točnije, poduzeća koja imaju divizijsku organizacijsku strukturu imaju veću efikasnost poslovanja od poduzeća koja imaju procesnu organizacijsku strukturu kod dva pokazatelja i to kod stope povrata na ukupnu imovinu (engl. Return Of Assest, ROA) i stope povrata na vlastiti kapital (engl. Return Of Equity, ROE). S druge strane, poduzeća koja imaju procesnu organizacijsku strukturu imaju veću efikasnost poslovanja od poduzeća koja imaju divizijsku organizacijsku strukturu kod dva pokazatelja i to kod neto profitne marže i bruto profitne marže.

Nadalje, izbor organizacijske strukture poduzeća se treba temeljiti na četiri faktora i to veličini poduzeća, strategiji, okolini i tehnologiji. Budući da je istraživanje pokazalo da od četiri faktora, na promjenu organizacijske strukture kod poduzeća u prehrambenoj industriji Splitsko-dalmatinske županije najviše utječu strategija i okolina, u testiranju druge temeljne istraživačke hipoteze rada pošlo se od pretpostavke da će poduzeća koja koriste strategiju, kao jedan od faktora utjecaja na izbor organizacijske strukture, imati veću efikasnost od poduzeća koja koriste okolinu prilikom izbora organizacijske strukture. Rezultati istraživanja su pokazali da postoji statistički značajna razlika između poduzeća koja koriste strategiju, kao jedan od faktora utjecaja na izbor organizacijske strukture i poduzeća koja koriste okolinu prilikom izbora organizacijske strukture čime je druga temeljna istraživačka hipoteza potvrđena.

\section{OGRANIČENJA ISTRAŽIVANJA I PREPORUKE ZA BUDUĆA ISTRAŽIVANJA}

Prilikom provođenja istraživanja za potrebe ovoga rada postajala su dva bitna ograničenja. Prvo ograničenje se odnosi na veličinu uzorka, koja je u ovome radu ipak primjerena s obzirom na značajke prehrambene industrije u Splitsko-dalmatinskoj županiji, ali koja bi trebala biti veća s obzirom na dokazivanje postajanja jače statističke veze između ispitanih varijabli. Drugo ograničenje odnosi se na nepostojanje usklađenosti u pojmovnom određenju tipova organizacijske strukture kod ispitanih poduzeća kojima su, prilikom provođe- 
nja istraživanja, trebala dodatna pojašnjenja kako bi identificirali koji je tip organizacijske strukture implementiran u njihovu poslovanju.

Uz ograničenja istraživanja, autori također predlažu preporuke za buduća istraživanja. Buduća istraživanja u ovome području trebala bi se odnositi na primjenu postojećih istraživačkih aktivnosti kod drugih industrija i to u utvrđivanju koji je tip organizacijske strukture karakterističan za istraživanu industriju i zašto, koji faktor najviše utječe na promjenu tipa organizacijske strukture kod poduzeća u istraživanim industrijama i zašto te kakav je utjecaj primijenjenih tipova organizacijskih struktura na efikasnost poduzeća u istraživanim industrijama. Uz to, prilikom provođenja budućih istraživanja trebalo bi također primijeniti komparativnu statistiku kako bi se ispitala postojanost razlike u utjecaju primijenjenih tipova organizacijskih struktura na efikasnost poduzeća između istraživanih industrija.

\section{LITERATURA:}

\section{Knjige i članci}

1. Abrahamson, E. (2000). Change Without Pain. Harvard Business Review, 78 (4), 75-79.

2. Ahmady, G., Nikooravesh, A., Mehrpour, M. (2016). Effect of Organizational Culture on knowledge Management Based on Denison Model. Procedia - Social and Behavioral Sciences, 230 (12), 387-395.

3. Buble, M. (2006). Management. Zagreb: Sinergija nakladništvo d.o.o.

4. Burnes, B. (2000). Managing Change - A Strategic Approach to Organizational Dynamics. Harlow: Prentice Hall.

5. Ghani, K., A., et al. (2002). Impact of advanced manufacturing technology on organizational structure. Journal ofHigh Technology Management Research, 13 (2), 158172.

6. Gupta, A. (1997). Determining organizational structure choices in advanced manufacturing technology management. International Journal of Management Science, 25 (5), 513-517.

7. Hernaus, T. (2009). Temelji organizacijskog dizajna, Serija članaka u nastajanju 0908. Zagreb: Ekonomski fakultet, <web.efzg.hr/RePEc/pdf/Clanak\%2009-08.pdf>. Pristupljeno 2. listopada 2017.

8. Mateljak, Ž., Bilić, I. (2012). Does type of organizational structures affect organizational performances? Case study of Croatia. Proceedings of the International Scientific Conference "From Global Crisis to Economic Growth. Which Way to Take?", Belgrade, Republic of Serbia, 925-930.

9. Medić, A. (2015.). Organizacijska struktura malih i srednjih poduzeća. Zagreb: Ekonomski fakultet, <https://urn.nsk.hr/urn:nbn:hr:148:682740>. Pristupljeno 18. svibnja 2017.

10. Nahm, A. Y., et al. (2003). The impact of organizational structure on time-based manufacturing and plant performance. Journal of Operations Management, 201 (3), 290-297. 
11. Salaj-Ćetković, V. (2009.). Komparativna analiza operativnog planiranja poduzeća u Hrvatskoj, Doktorska disertacija. Zagreb: Ekonomski fakultet Zagreb.

12. Sikavica, P., Bahtijarević-Šiber, F., Pološki-Vokić, N. (2008.). Temelji menadžmenta. Zagreb: Školska knjiga.

13. Sikavica, P., Novak, M. (1999.). Poslovna organizacija. Zagreb: Informator.

14. Zheng, W. et al. (2010). Linking organizational culture, structure, strategy, and organizational effectiveness: Mediating role of knowledge management. Journal of Business Research, 63 (7), 765-779.

15. Žugaj, M., Brčić, R. (2003.). Menadžment. Varaždin: Fakultet organizacije i informatike.

\section{Ostali izvori}

16. Pokazatelji uspješnosti poslovanja, Materijali s predavanja. Zagreb: Sveučilište u Zagrebu, www.pbf.unizg.hr, pristupljeno 29. lipnja 2017. 